\title{
ENVISIONING SUSTAINABLE LANDSCAPE MANAGEMENT IN THE ENVIRONMENTALLY SENSITIVE AREAS OF KSOUR ESSEF, TUNISIA
}

\author{
Faiza Khebour Allouche 1, 2, Saida Hammami ${ }^{1}$, Arwa Hamaideh ${ }^{3}{ }^{凶}$, Emna Gatta ${ }^{1}$, \\ Anas Khasawneh ${ }^{4}$ \\ ${ }^{1}$ High Institute of Agronomic Sciences-Chott Meriem, University of Sousse, Tunisia \\ 2 GREEN TEAM Laboratory, University of Carthage, Tunisia \\ 3 Water, Environment, Center Energy research. University of Jordan, Jordan \\ ${ }^{4}$ Jordan Association for Building Environment and Sustainable Development, Jordan
}

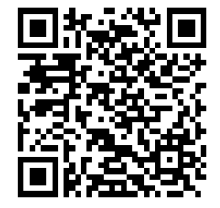

DOI: https://doi.org/10.29121/granthaalayah.v9.i1.2021.2715

Article Type: Research Article

Article Citation: Faiza Khebour Allouche, Saida Hammami, Arwa Hamaideh, Emna Gatta, and Anas Khasawneh. (2021). ENVISIONING SUSTAINABLE LANDSCAPE MANAGEMENT IN THE ENVIRONMENTALLY SENSITIVE AREAS OF KSOUR ESSEF, TUNISIA. International Journal of Research GRANTHAALAYAH, 9(1), 85-98. https://doi.org/10.29121/granthaa layah.v9.11.2021.2715

Received Date: 11 December 2020

Accepted Date: 27 January 2021

Keywords:

ESA

Landscape

Diagnosis

Urban Natural Park

\begin{abstract}
Each territory has distinctive features and landscape compositions that contribute to the creation of territorial identities. Natural parks are territories remarkable for their wealth of biodiversity, which in turn contribute to the development of sustainable socio-economic development through landscape enhancement. The main idea of this research is to test the combinaison of two concepts to propose a suitable management in a semi-arid environment. It is based on the use of the ESAs and landscape diagnosis concepts. The concept of ESAs is supported including the need to identify environnementally sensitive lands based on the hypotheses of MEDALUS project model. However, the landscape diagnosis is based on the combination of landscape potential and social requirements. Results aimed to create ecological and environmental models based on natural materials such as wood, light minerals and a diversified and multicoloured plant palette, including the logic of working with nature and preserving its particularity by promoting sustainable local development criteria and create a new green city.
\end{abstract}

\section{INTRODUCTION}

Since the early 19th century, forests have been the scene of urban growth and have sometimes been transformed into green and wooded areas or urban forest parks. With the evolution of large urban areas, the need for space for new construction has caused problems following deforestation, fires and the degradation of peri-urban natural areas. Today, despite these disadvantages, several countries have become more aware of and respectful of periurban forests through the development of fields of activity in these areas. Forests are multifunctional spaces, offering both tangible and intangible services. In Japan or Australia, the demand for recreational spaces has encouraged public authorities and local authorities to invest in forests to benefit from their environmental and social functions. In France, the social perception and representation of forests are very closely linked to leisure activities (Papillon,

(C) 2021 The Author(s). This is an open access article distributed under the terms of the Creative Commons Attribution License, which permits unrestricted use, distribution, and reproduction in any medium, provided the original author and source are credited. 
2014). In Tunisia, peri-urban forests were transformed into public parks in the summer following the program of 100 parks that began in 1996. The objectives of creating these parks are essentially to improve the living conditions of city dwellers and to preserve the natural spaces adjacent to the cities. Among the forests that have been transformed into public parks are (Nahli, El Mourouj, Farhat Hached, El Hmeda,...). Today, these forests converted into peri-urban parks do not meet society's needs for a pleasant natural living environment and also for leisure. Periurban forests require new recognition and also a rethinking of their future. The example of the Ksour Essef periurban park is our study support, in order to assess its current state and propose solutions that can remedy the disadvantages and offer the target population a better living environment in order to preserve natural resources while meeting the requirements of sustainable development. Generally, landscaping projects are based on landscape analysis, this research work consists in presenting a method of evaluating the landscape features of a regional forest natural park which has been developed in 2011 but has undergone a significant degradation of natural and managed entities following the effect of climate change and anthropogenic especially after the revolution. The status of sensitive environmental areas will be assessed by applying the Medalus method. Then, a landscape diagnosis is carried out on the ground. The comparison of the results will enable to better manage the studied space and propose a sustainable landscaping taking into account the three pillars of sustainable development.

\section{STUDY AREA}

The park is located in the delegation Ksour Essef belongs to the governorate of Mahdia and occupies an area of 16 hectares which implanted in a forest of an overall area of 50 hectares (Figure 1). This space was actually an old stone quarry in the sixties, which after its closure in 2001, was promoted as a green space. It occupies the highest point of the city whose altitude can reach up to $66 \mathrm{~m}$. This forest represents the green lung of the city, thus, it is formed of an afforestation of Aleppo pine "Pinus Halepensis" and Eucalyptus "Eucalyptus Camaldulensis". The development of the park is part of the national parks program that brings together 100 parks throughout Tunisia to improve the living environment of the population and the protection of the environment. It was open, according to the municipality of Ksour Essef, in 2002 and was valued as a forest park. Indeed, a wrought iron fence was put in place to demarcate the park and protect it with an entrance gate made by AUDEC (2002), with a sum of 28 thousand dinars. Inside the park, a fitness trail was set up in 2011 with all the physical work equipment, a refreshment bar, a play area, a "LABIB" pedestal and family rest areas with benches. But since the Tunisian revolution, in 2011, the space was destroyed and poorly maintained, therefore, it became non-functional and a wealth of landscape was lost including the components of the course.

The delegation of Ksour Essef belongs to the governorate of Mahdia located south-east of the Tunisian sahel, $200 \mathrm{~km}$ from the capital Tunis and $12 \mathrm{~km}$ from the city of Mahdia with an area of $40 \mathrm{Km}^{2}$ and 54366 inhabitants in 2014. It is located on a moderate hill, and encloses a coastal zone stretching $13 \mathrm{Km}$ (Figure 1). According to the National Meteorological Institute of Tunis (2017), the city of Ksour Essef is known for a warm, dry Mediterranean climate in summer, humid and temperate in winter with a maximum average temperature of $31^{\circ} \mathrm{C}$ and a minimum average of $6^{\circ} \mathrm{C}$. The city is also known by winds on the east side in summer and on the west side in winter, whose west winds are dominant and can reach up to $80 \mathrm{~m} / \mathrm{s}$. Potential evapotranspiration (PET) varies from 1319 to 1321 $\mathrm{mm}$ / year in 2010. According to the Regional Commissariat for Agricultural Development (CRDA, 2014), Ksour Essef contains the water table "Melloulech", where 1446 water wells produce 2.91 million $\mathrm{m}^{3}$ /year with a variable salinity between 3 to $15 \mathrm{~g} / \mathrm{l}$. It belongs to the "Sahel Sfax" water table, consisting of 22 water wells, producing 3.15 million $\mathrm{m}^{3}$ of water. The Territorial Extension Cell (CTV, 2002), has mentioned that the irrigated perimeters at Ksour Essef occupy a total of 110 hectares spread over 152 farmers. It despites a water salinity of $4.3 \mathrm{~g} / \mathrm{l}$ of salt. However, Ksour Essef is built on a succession of hills with altitudes that vary between $6 \mathrm{~m}$ and $30 \mathrm{~m}$ and the neighboring altitude hills reaches $65 \mathrm{~m}$. 

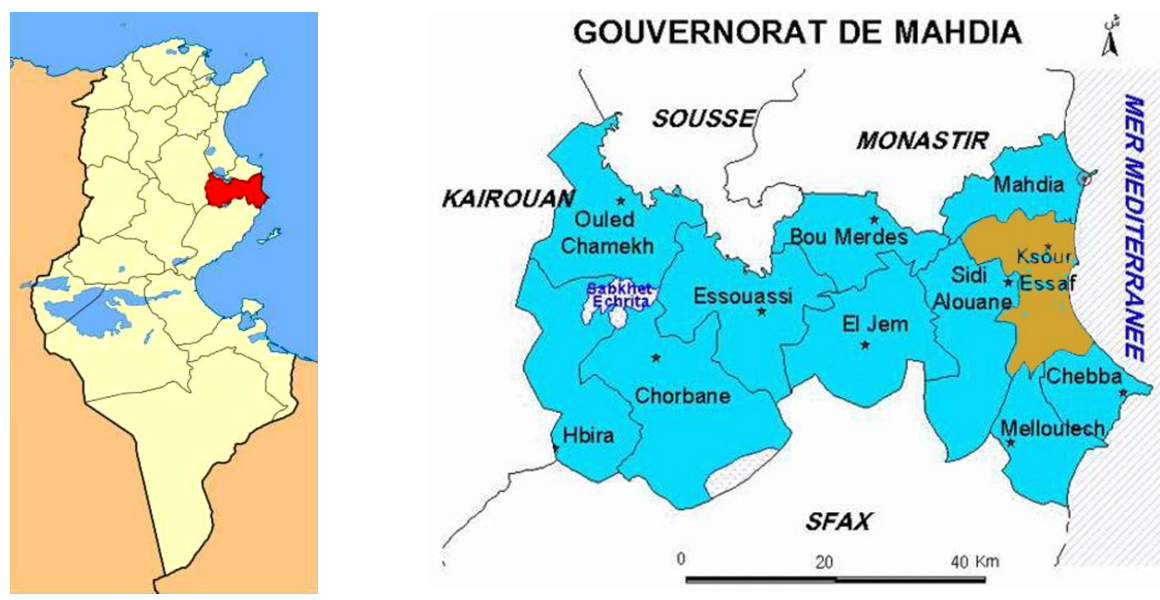

Figure 1: Location of Ksour Essef city, Tunisia

The delegation of Ksour Essef is home to several types of soils, and the predominance of low input soils, isohumic soils and raw mineral soils on the north side. In the southern part, the soils are raw limestones, while in the center there is a diversity such as halomorphic soils, rendzines and complex units. The raw mineral soils are located on a steep slope where the surface layers are constantly entrained thus preventing the formation of soil from which the vegetation cover is very insignificant. This type of soil is mainly present in the northern and north-eastern part of Ksour Essef, with a succession of hills reachs $66 \mathrm{~m}$. The poorly evolved soils are generally located in semi-arid areas, characterized by a low degree of weathering, a humic horizon and a structure that is often weak. Isohumic soils are characterized by a dominance of clays found in the forest of Ksour Essef (Figure 2). The land use of the town of Ksour Essef is subdivided into two parts: the coastal side presents a variety of crops including cereals (barley and wheat), forage crops (sorghum, maize, oats ...), market gardening (pepper, tomato, potato, zucchini, cucumber, carrot, onion, melon, eggplant, pea, squash, watermelon, garlic ...), spices (cumin, choriambe) and olive groves. Further, cereal crops persist in the west one (Figure 3).

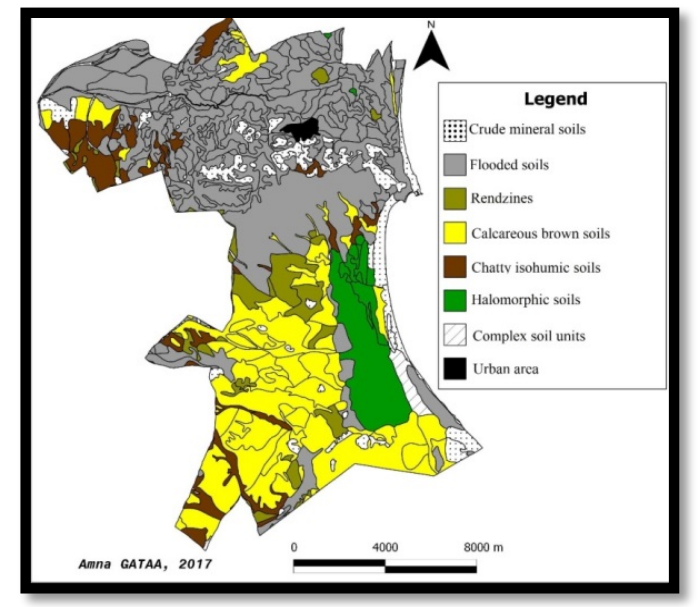

Figure 2: Different soil types of the Ksour Essef delegation, Tunisia

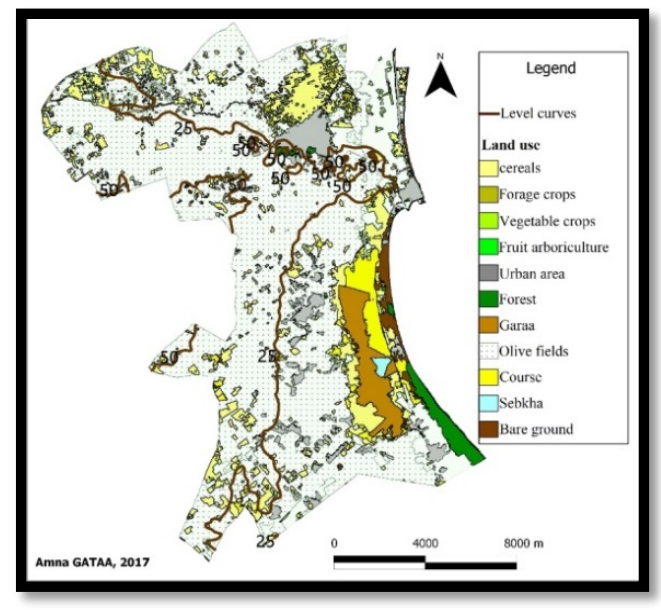

Figure 3: Different soil types of the Ksour Essef delegation, Tunisia

The commune of Ksour Essef, contains 12 green spaces with a total area of 353,950 $\mathrm{m}^{2}$ distributed as follows:

- Habib Bourguiba Street Garden: $2500 \mathrm{~m}^{2}$ (under redevelopment)

- Hedi Chaker Street Garden: $1850 \mathrm{~m}^{2}$ (in redevelopment study)

- Ahmed Tlili Street Garden: 1,800 m² (requires maintenance)

- Omar Karchoud Street Garden: $400 \mathrm{~m}^{2}$ (requires maintenance)

- Ali Bouzidi Street Garden: $2000 \mathrm{~m}^{2}$ (in redevelopment study)

- El Hmeda Park: $160000 \mathrm{~m}^{2}$ (in redevelopment study)

International Journal of Research -GRANTHAALAYAH 
- Garden Aziza Othmena street: $78300 \mathrm{~m}^{2}$ (corner bush)

- Garden rue Salah Eddin El Ayoubi: $20100 \mathrm{~m}^{2}$ (corner bushed)

- Garden Bizerte street: $8200 \mathrm{~m}^{2}$ (bushed area)

- Garden Jbal Khmir street: $78400 \mathrm{~m}^{2}$ (corner bush)

- Garden Street 2 Mars: $300 \mathrm{~m}^{2}$ (in redevelopment study)

- Garden street Abdallah Chaweli: $100 \mathrm{~m}^{2}$ (corner bush).

The delegation of Ksour Essef has a population of 54,366 inhabitants in 2014. The economic development of the city of Ksour Essef is based on the trade where there are more than 300 points of sale in detail. The participation rate is $38.87 \%$ while the unemployment rate is $9.83 \%$, which shows that despite the reduction in the number of jobs in the city, agriculture and commerce provide a lot of jobs (INS, 2014). During the last five years, the city has undergone remarkable development especially in the administrative, health, educational, sports, cultural, religious and commercial (Monoprix, Carrefour, etc.).

\section{METHOD}

Urban Natural Parks are designed to preserve and improve the quality of the landscapes and the living environment of the inhabitants. As a result, the need for green spaces in cities is becoming a necessity, and city dwellers are looking for moments of relaxation, rest, recreation, outdoor activities and sports where nature is very calm. In this strategy that the municipality of Ksour Essef has requested a proposal for the redevelopment of the El Hmeda natural urban park, which is part of the sustainable development project of Mahdia city. In response to this request, the objective of this research is to propose a landscaping redevelopment in this park. The methodological approach is based on the ESA approach and the landscape analysis dealing with the different physical, sensitive and natural aspects and the development proposal is based on the concept "Treasure Hunt". In order to understand and act effectively on the Ksour essef park, we opt for an analytical approach based on diagnosis and evaluations, as shown in Figure 4, different steps followed in the methodological approach.Two principal steps are used the landscape diagnosis and the ESA assessment of park El Hmeda

The physical diagnosis is based on the use of Google earth, open street map and some shapefiles. Google earth and field validation using GPS are done for digitizing and mapping the spatial delimitation of the park, slope and altitude variation for two transects, it's land use cover and field description of some stations. The park accessibility is mapped using Open street map tool and some benchmarks are located. However, sensitive analysis is based on the visual interpretation of the landscape structure (vertical and horizontal), noise, and colors in order to evaluate its state. The survey conducted as part of this research, aims to know the expectations of the resident population around the forest of El Hmeda and visitors to approve our idea of design. Ten questions in total were asked, out of 50 people, some are asked in a socio-economic context such as age, sex, the budget devoted to leisure, the distance between the park and the housing of the person surveyed. Others are asked to better understand the strengths and weaknesses of the space, the reasons for the visit, the preferred locations and the expectations of the new landscaping.

The use of this diagnosis method is based on the hypotheses of MEDALUS project model (Giordano et al., 2007). Three qualitative indexes are computed by applying an average of a geometrical model. The following three quality indices were computed;

- Soil Quality Index (SQI),

- Vegetation Quality Index (VQI)

- Climatic Quality Index (CQI)

Administrative, land use land cover and sol Mahdia vector layers are used to map and calculate indexes. DEM raster layer was downloaded from https://glovis.usgs.gov/ and used to retrieve the slopes and aspect gradients. The data (spatial resolution of $30 \mathrm{~m}$ ). The evaluation of ESAs is based on a combination of the physical including soil, climate, and vegetation qualities. A geodatabase and several thematic maps were prepared and standardized with the same projection system and spatial resolution. The indicators were grouped into four quality indices, namely, the soil quality index (SQI), climate quality index (CQI), vegetation quality index (VQI), and MQI (Khebour_Allouche and Gad, 2014). Each indicator was calculated by means of sub-indicators, which were also classified. For each class, 
a weight value was allocated. The values of the weights varied from 1 (least sensitive to desertification), to 2 (most sensitive to desertification) (Gad and Lotfi, 2008).

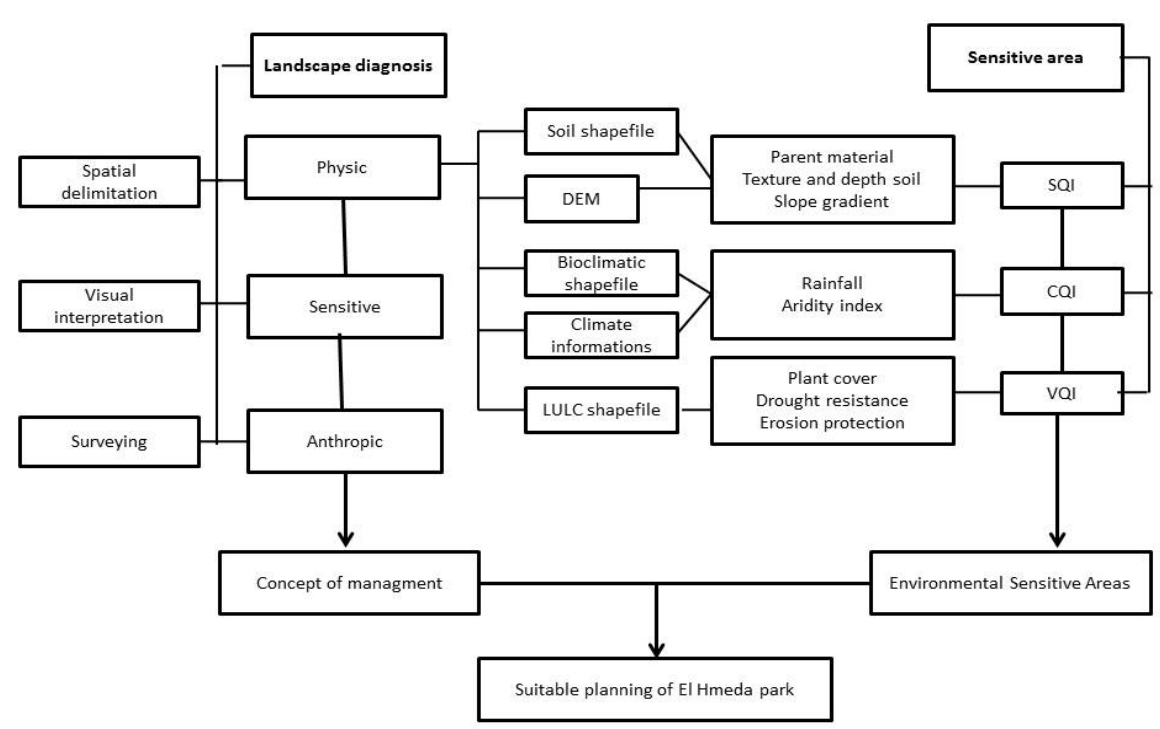

Figure 4: The landscape diagnosis and the ESA assessment of park El Hmeda, Tunisia

\section{RESULTS AND DISCUSSION}

\subsection{ASSESSMENT OF SENSITIVE AREAS}

A large part of the park is located in a quaternary formation. The quaternary part includes terraces of major bed, mobile sand, unconsolidated scree, low terraces, dejection cones, and white limestones, probably lacustrine and often conglomeratic. Furthermore, the Ordovician part contains sandstone, quartzites, and claystone. Soils derived from different parent materials react differently to erosion, absorbency and production of biomass: the presence of pebbles still causes an increase in runoff and therefore improved safeguard from desertification (Figure4). The influence of each class for each sub-indicator constructs SQI that was weighted based the influence on desertification process. More than $50 \%$ of the area is marked by less sensitive soils. A strip which crosses this entity in the center of the forest area is marked by moderately sensitive soils. These landscape conditions encourage sensitivity to land degradation. Calculating the vegetation quality index, on basis of the previous parameters reveal that the $60 \%$ of the vegetation cover is very weak and sensitive to desertification (Figure5). The good vegetation index class which may resist desertification is represented olive plots. The Hmeda park have an average of a precipitation of $283 \mathrm{~mm} / \mathrm{a}$ and the PET is inferior to $1300 \mathrm{~mm} / \mathrm{an}$. So, the climatic quality index is inferior to 0,217 . That's why all the field have a weak climatic index. Figure 6 show the distribution of ESA's. It is clear that most of the Hemeda park is moderately sensitive to desertification (60\%) and the very sensitive area is located in the east.

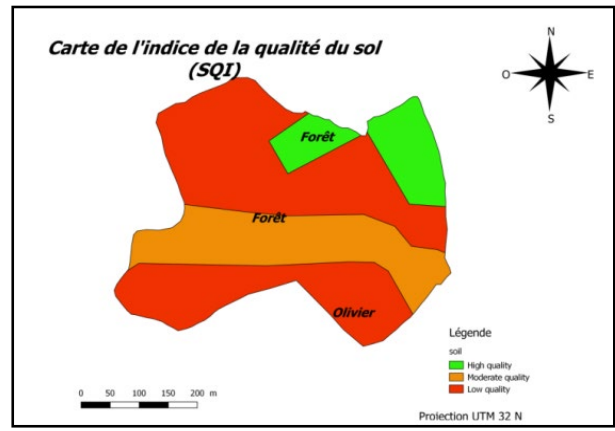

Figure 4: SQI map of El Hmeda park International Journal of Research -GRANTHAALAYAH

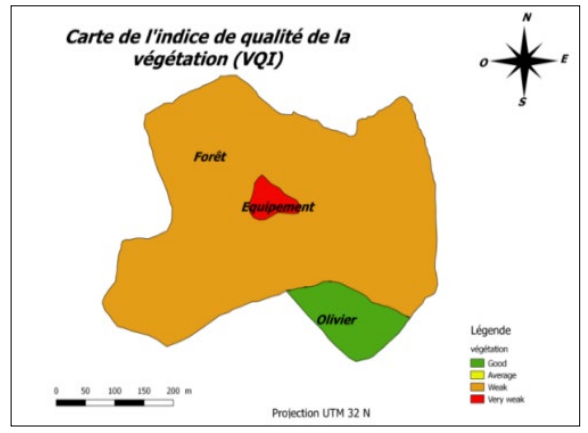

Figure 5. DSI map of El Hmeda park 

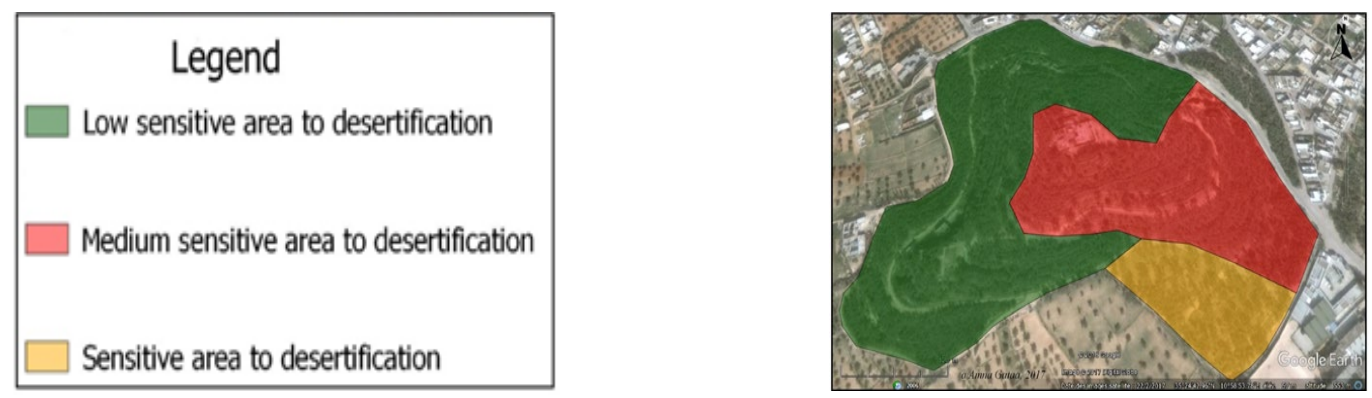

Figure 6: ESA's for desertification in El Hmeda park

Through the geographical evaluation of the park, in order to qualify the different biotic (plant and soil) and abiotic (climate) components, it can be concluded that the El Hmeda peri-urban park is a natural space whose distribution of natural resources is not very equitable throughout the park, which leads to rethink landscape development through conservation and remediation planning. In this respect, a landscape analysis is essential to meet the requirements of a functional and sustainable development.

\subsection{LANDSCAPE ANALYSIS}

\subsubsection{PHYSICAL ANALYSIS}

The physical analysis is based on the description during field visits and the use of digital media such as Google Earth, Google maps and QGIS 1.18. The park is accessible from the Mahdia-Ksour Essef road via Rojich on the north side or on the west side by the Salakta-Ksour Essef road. It is surrounded by three types of landscapes: an urban landscape constituting the center of the city of Ksour Essef, a peri-urban landscape formed by the extensions of the city and a wider agrarian landscape formed by olive groves. The slope in the park to be redeveloped is very specific which gives it a unique charm following the variation of the slopes, the division of the land into three terraces and rugged terrain. A longitudinal plot shown in Figure 7 shows that the park represents a variation in altitude between $27 \mathrm{~m}$ and $58 \mathrm{~m}$. While the transverse plot of the same figure indicates a variation between $32 \mathrm{~m}$ and $61 \mathrm{~m}$.

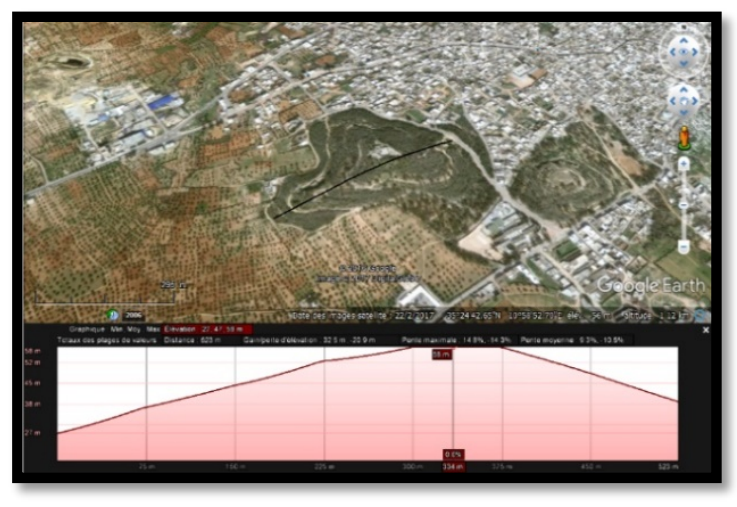

a. Variation of altitudes in horizontal

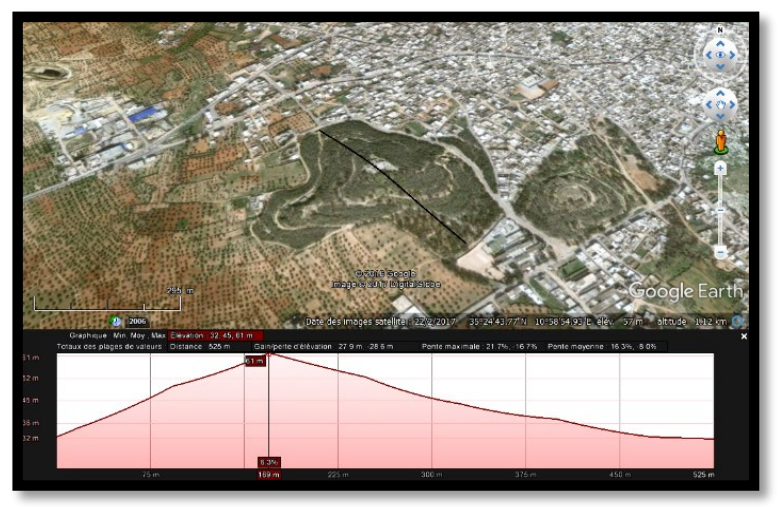

b. Variation of altitudes in vertical

Figure 7: Altitudes variation in Ksour Essef park

Aleppo pine occupies more than $90 \%$ of the total area of the park with variable densities shown in Figure 8. The northern part represents a high-density Aleppo pine plantation, the eastern part contains a medium density and the Southern part is rather at very low density. These woodlots are crossed by trails and tracks representing respectively $23 \%$ and $77 \%$ of accessible linear parts ensuring the circulation throughout the park. 


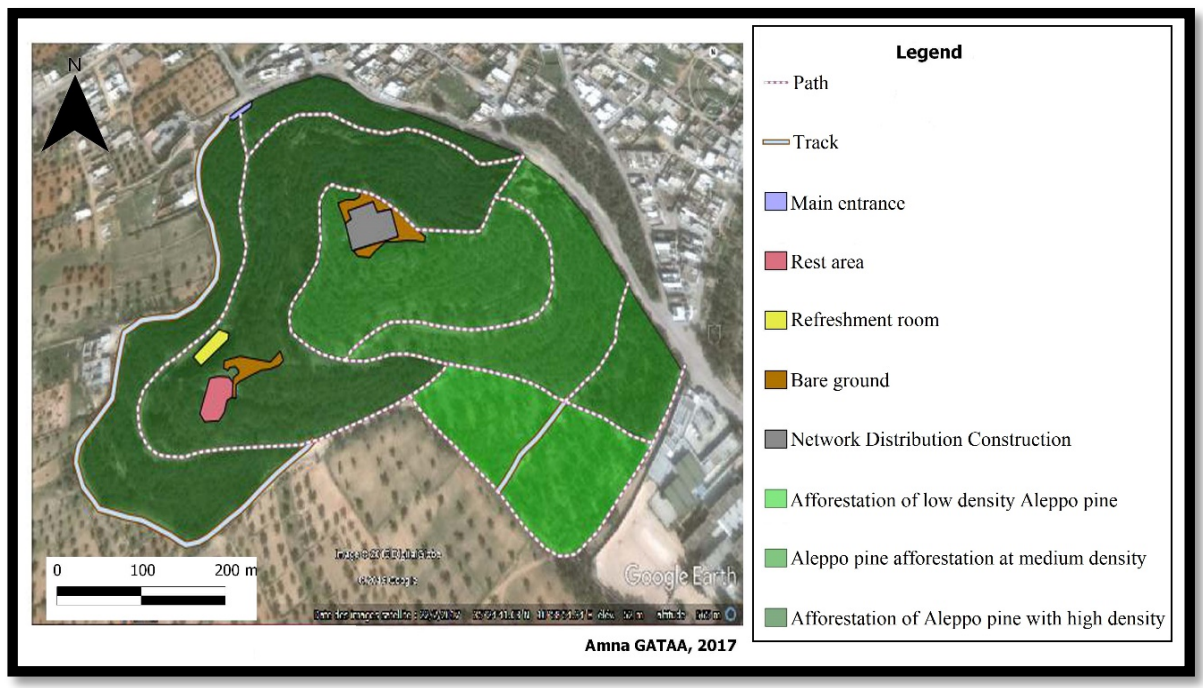

Figure 8: Components and circulation in the Ksour Essef Forest Park, Tunisia

GPS points were taken during the field trip using the Garmin Map 64S. Table (5) shows the description of some stop stations where GPS points were taken. The first station corresponds to the main entrance on the north side, characterized by rough terrain and a destroyed fence. The second station is related to one of the caves constituting the park. Stations 3 and 4 present the local and distribution pole of the network. And the last station is a secondary entrance on the south-east side.

Table 1: Description of some the forest parc Ksour Essef stations

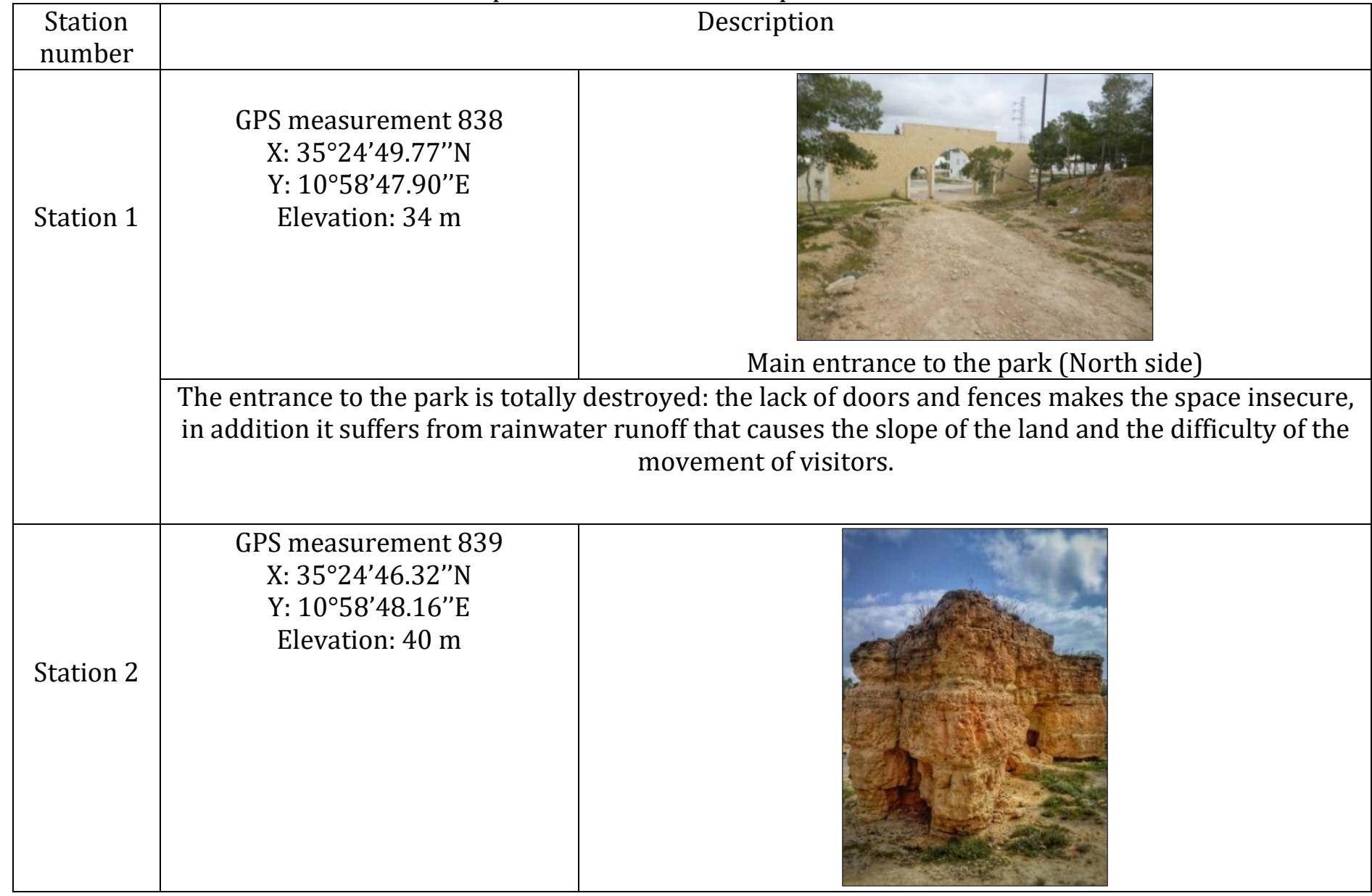




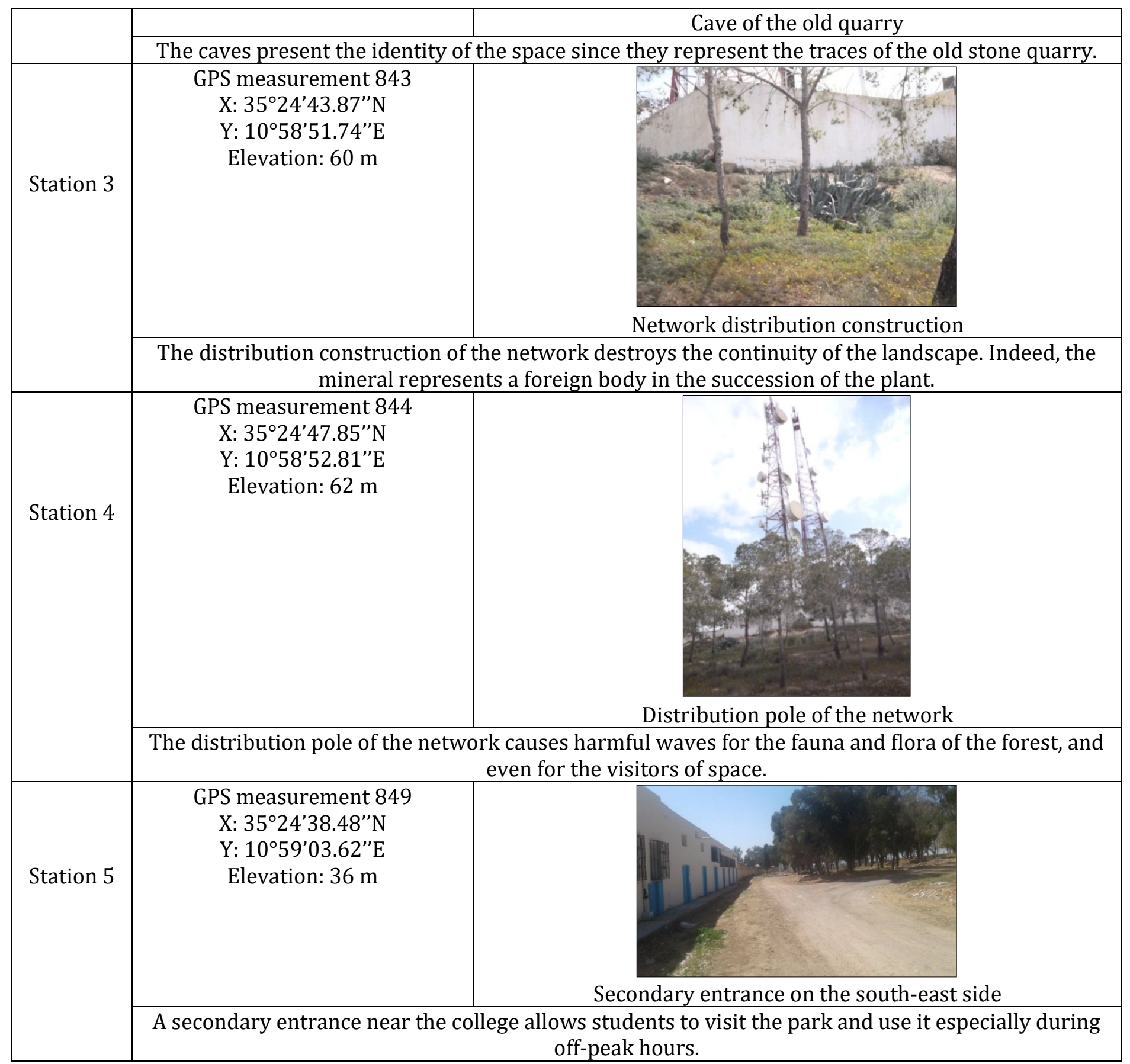

\subsubsection{SENSITIVE ANALYSIS}

The park represents the green lung and the only virgin space in the city. It is a vast place that gives the impression of freedom. The game of altitudes presents the strongest point, it offers an open panoramic view allowing to even the whole city of Ksour Essef and even its peripheries. However, the park lacks dynamics and flexibility as the verticality of conifers dominates with a yellowish-green color and more yellowish in places reflecting the soil giving the impression of sadness and emptiness. The slopes are also a weak point; for example, the lower part of the park on the north side is the most damaged mainly by rainwater runoff and there the terrain becomes very rough and makes the movement very difficult especially for the elderly. Thus the lack of water, lighting, furniture and especially security makes the space abandoned (Figure 9). 


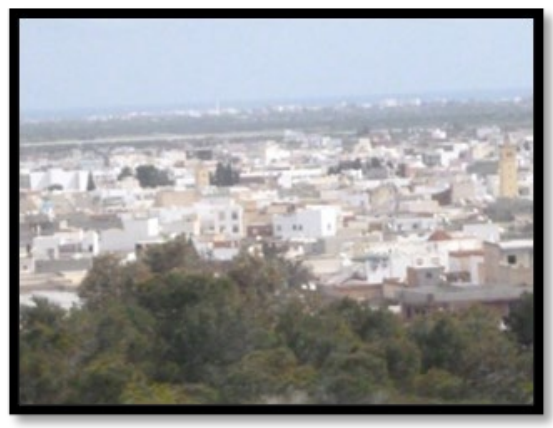

Open panoramic view of the highest point of space

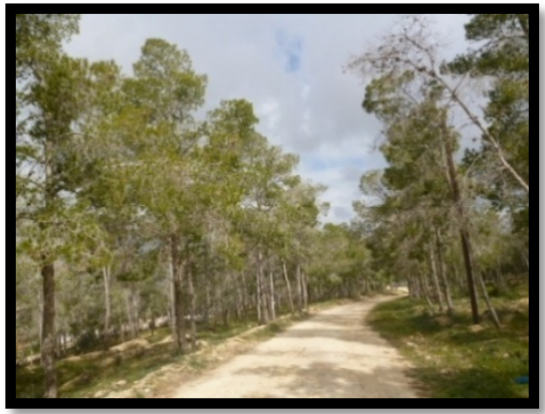

Dominance of verticality and yellowish-green color of "Pinus Halepensis"
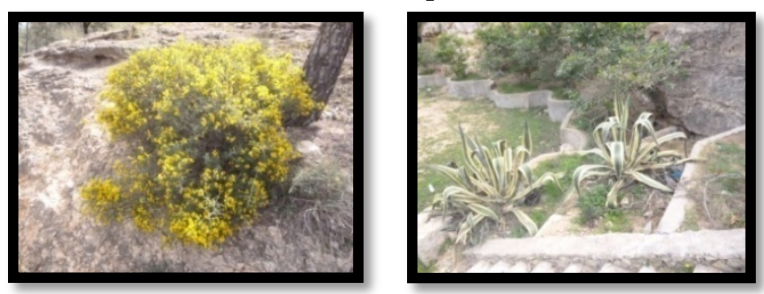

Original vegetation of the forest

Figure 9: Some examples illustrating the sensitive analysis of Hemada Park, Tunisia

\subsubsection{ANTHROPIC ANALYSIS}

Figure 10 shows that age groups of visitors are divided into 5 classes. The park is more visited by adults, whose age is over 50 years (26\%), then comes in second place the class of visitors aged between 40 to 50 years. $20 \%$ is the percentage of visitors for both classes in the 30 to 40 and 20 to 30 age groups. The lowest percentage, $10 \%$, represents the class of the youngest visitors (10 to 20 years old). In addition, $54 \%$ of visitors are represented by the male sex, while the female sex represents only $46 \%$.
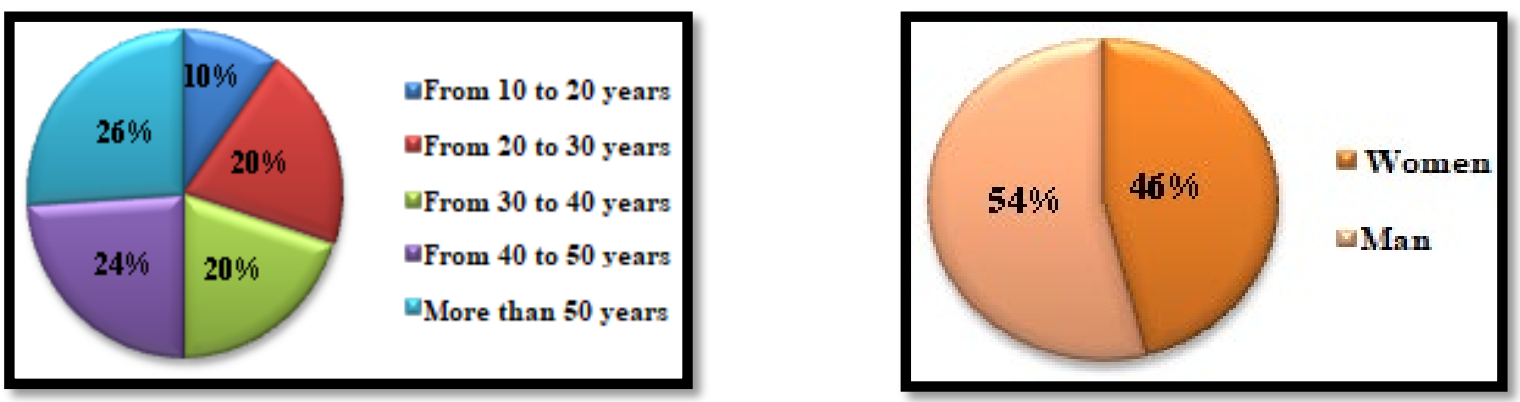

Figure 10: Percentage change in age groups (left) and visitor gender (right) of El Hmeda Park 
The majority of park visitors come from Ksour Essef (58\%) and Salakta (42\%). Thus, $28 \%$ of visitors take five minutes by car to access the park and $24 \%$ of visitors arrive on foot.
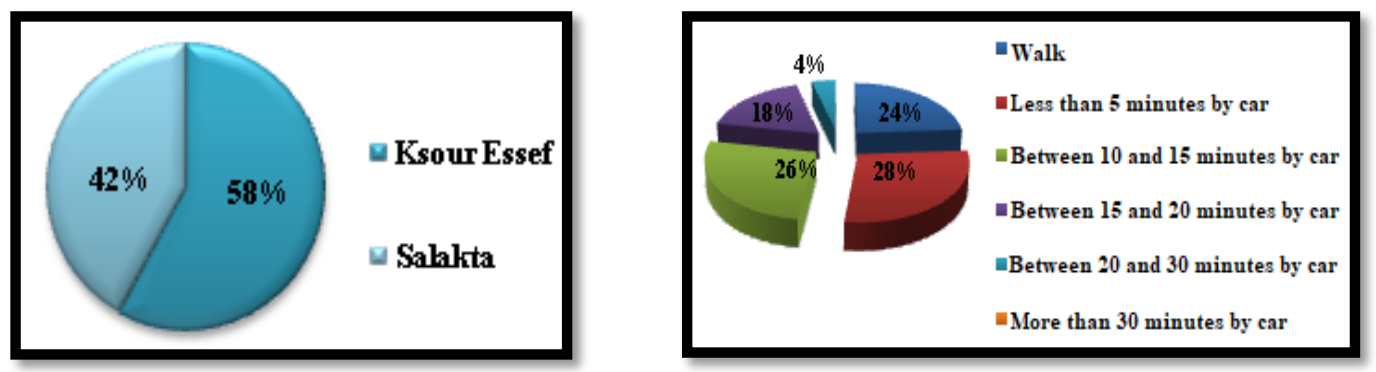

Figure 11: Percentage change in visitor origins (left) and time required to access (right) El Hmeda Park, Tunisia

The percentages of park attendance range from $4 \%$ to $30 \%$. From Figure 30, we note that the majority of visitors go to the park infrequently and $28 \%$ of visitors have never visited it, this is their first visit. The frequency varies between once a week and a fortnight (14\% for each type). While, the budget devoted generally to leisure by these visitors vary between 5 and 20 dinars a week. Most visitors consume only 5 dinars per week for leisure (32\%), almost $50 \%$ of visitors consume between 6 and 20 dinars a week, and only $8 \%$ of visitors spend more than 20 dinars a week.
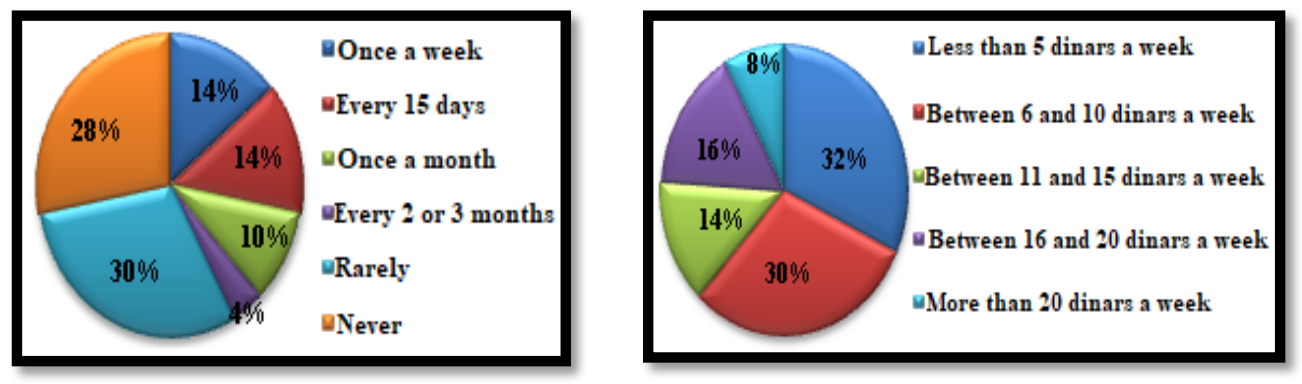

Figure 12: Variation in percentages of attendance (left) and leisure budget per week by visitors (right) of El Hmeda Park, Tunisia

Figure 13 shows that $60 \%$ of visitors find the park to be a great place to relax, and $32 \%$ see it as useful for hiking and some sporting activities. Only $8 \%$ of visitors use the park for its calm. Thus, the totality of the surveyed visitors considered that the main asset of the park is the nature and that the lack of security represents the most important constraint. Regarding the question on the facilities proposed by the visitors within the park: $25 \%$ of the visitors claim the importance of the presence of a playground for child, $22 \%$ a course of health and $20 \%$ a restaurant cafe. The lowest percentages consider the development interest in descending order of reading, barbecue, picnic and a mini zoo.
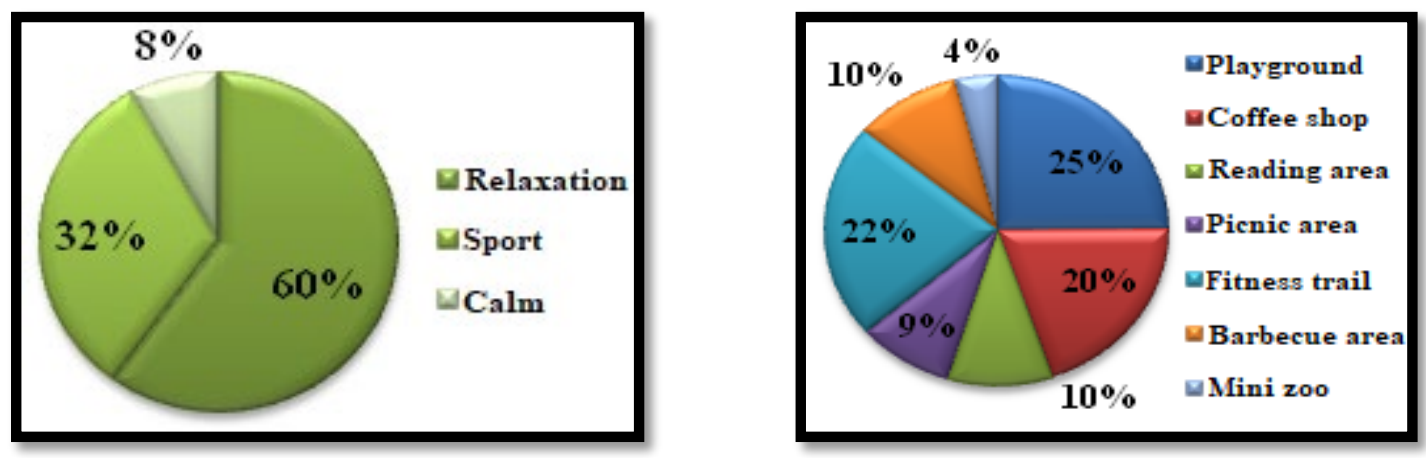

Figure 13: Percent change in visit reasons (left) and planning proposals (right) of the park "El Hmeda", Tunisia 


\subsection{CONCEPT REDEVELOPMENT: "THE TREASURE HUNT"}

Table 2 represents a summary of the information retrieved from the study area to express the strengths and weaknesses of the studied space that can be used later for the idea of redevelopment. The park to be redeveloped is a natural urban park, located on a hill, offering a panoramic view of the entire city of Ksour Essef. It has a very large area, with unevenness and differences in slopes presented in the form of paths that snake. Thus, the relief is not very marked, ruiniform because of the calcareous texture of the soil. The rocks are sharp by the slow persistent erosion caused by water and wind. This natural park is marked by the afforestation of "Pinus halepensis" with isolated silhouettes and the grouping of groves gives it a dark green color especially in the northern part. However, this mass of pines encloses the views close by closing the landscape and hides the distant views. The elevation of the park represents the main element in the structuring of the space, it is the point on which will be based all the proposal of the development. However, the park suffers from some constraints that must be solved to achieve the proposed development. These obstacles include lack of water points and lack of security.

Table 2: Assessment of the landscape analysis

\begin{tabular}{|c|c|c|c|c|}
\hline & Components & Assets & Constraints & Balance sheet \\
\hline \multirow{5}{*}{$\begin{array}{l}\text { Physical } \\
\text { study }\end{array}$} & Area & Important & - & Diversity of development \\
\hline & Elevation & Panoramic view & - & Valuing the upper part \\
\hline & $\begin{array}{l}\text { Hydrographic } \\
\text { network }\end{array}$ & - & Lack of water source & Dig a survey \\
\hline & $\begin{array}{c}\text { Isohumic and } \\
\text { rocky soil }\end{array}$ & - & Erosion problem & Reforestation \\
\hline & Vegetation & «Pinus Halepensis » & Degraded state & $\begin{array}{l}\text { Diversification of the plant } \\
\text { palette }\end{array}$ \\
\hline \multirow[b]{6}{*}{$\begin{array}{l}\text { Sensitive } \\
\text { study }\end{array}$} & Opening & Large space & Security problem & $\begin{array}{l}\text { Delimitation of space by a } \\
\text { fence }\end{array}$ \\
\hline & Verticality & - & Dead view & Using flexible forms \\
\hline & Colors & Nature & $\begin{array}{c}\text { Absence de diversity et } \\
\text { vivacity }\end{array}$ & Insertion of colored elements \\
\hline & Rough terrain & Dynamism & Difficulty of movement & Smooth the trails \\
\hline & Difference of levels & Leveled space & Some hidden views & Valorization \\
\hline & Sound and noise & $\begin{array}{c}\text { Sound of birds and tree } \\
\text { leaves }\end{array}$ & $\begin{array}{l}\text { Noise pollution of } \\
\text { roads }\end{array}$ & Sound barrier \\
\hline \multirow{7}{*}{$\begin{array}{l}\text { Anthropic } \\
\text { study }\end{array}$} & Age groups & Profiles diversity & - & \multirow{7}{*}{$\begin{array}{l}\text { Propose a more attractive } \\
\text { redevelopment }\end{array}$} \\
\hline & Sex & & & \\
\hline & Origin & - & Limits of frequentation & \\
\hline & Relaxation budget & - & Low & \\
\hline & Distance & $\begin{array}{l}\text { Most visitors are not far } \\
\text { from the park }\end{array}$ & Unknown space & \\
\hline & Frequency of visit & - & Rare & \\
\hline & $\begin{array}{l}\text { Main raison for } \\
\text { visits }\end{array}$ & Relaxation in nature & - & \\
\hline
\end{tabular}

The proposed concept aims to enhance the strengths of space created by nature and based on its physical criterion, mainly its altitude difference. Thus, three levels of development will be presented giving the impression of a treasure hunt adventure where in each part a different atmosphere will be discovered: i) the first is characterized by a flat earth and a very Aleppo pine wood. dense, ii) the second has a resting family space and iii) the third is characterized by a panoramic view open to the whole city. The main objective of this redevelopment is the sustainability of the space, while seeking to promote the meeting of people and the practice of sports activities, thus reducing stress and improving the health of visitors. The environmental aspect is reflected in the use of wood in the majority of furniture, and the densification and variation of plants to create a green lung and improve the living 
environment of the population. Finally, the development of the economic aspect will be favored by the inclusion of refreshments and games.

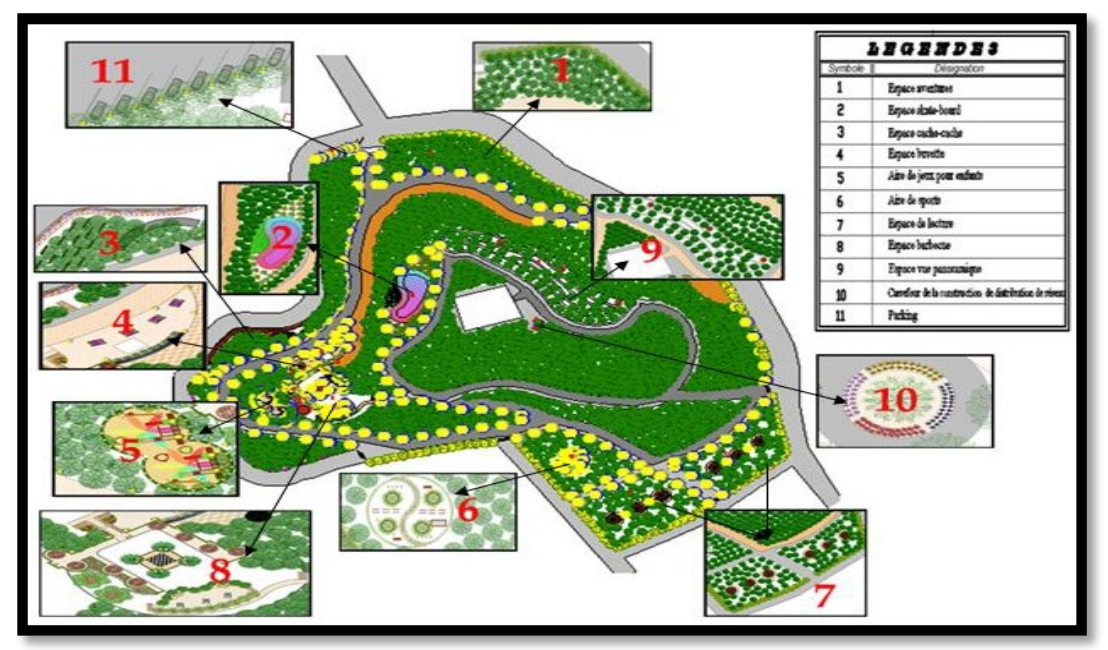

Figure 14: Redevelopment plan for El Hmeda Park, Ksour Essef, Tunisia, presenting 11 entities: (1) Adventure area - (2) Skateboard space - (3) Hide-and-seek area - (4) Bar area - (5) Children's play area - (6) Sports area - (7) Reading area - (8) BBQ area - (9) Panoramic view area - (10) Crossroads of network distribution construction and (11) Car park

\subsection{THE PROPOSED SUSTAINABLE PLANNING}

Entity 1: The Adventure area presents the first component of the first treasure "adventure in good health"; it is a kind of game: climbing trees since this part has a very high density of "Pinus halepensis" which helps the implementation of furniture of this game. Upon entry a sign, containing the necessary information (presentation of the game, how to play and ages of users), is put to give a general idea about the activity to be done. This game is a kind of wooden cylinders fixed on tree trunks connected together by ropes and nets must be climbed. Benches and bins are scattered on both sides and candelabra installed to ensure the use of space during the night. In addition, a fence followed by an alignment of "Acacia dilbata" proposed for more security.

Entity 2: The Skateboard space presents the second component of the first treasure. It consists of a large skateboard stage and a climbing game built on a natural rock. This part begins with a sign giving information on the activities that are dedicated for young people (skateboarding scene) and for children between 6 and 12 years old (climbing game). The vegetation is very simple composed of "Pinus halepensis" with 22 "Pinus pinea", without forgetting the benches and lighting.

Entity 3: The Hide and Seek Space are dedicated for children between 3 and 12 years old. It is built of a set of wooden plates pinted in red constituting the game of hide and seek and a net for the activity of the climb. This part of the park is suitable for this type of activity thanks to the high density of "Pinus halepensis". Thus, a fence protects her, hidden by a red and mauve Bouganvillea glabra gardener, and accompanied by a wooden bench and candelabra for the light.

Entity 4: The refreshment Bar area room presents the fourth component of the first "adventure in good health" treasure. It is a forest-style space marked by an artificial waterfall, located on a natural rock, led by a floral flower planter composed of "Antirrhuim majus", "Lathyrus adoratus", and "Tagetes patula" lit by recessed floors colored. Four wooden pergolas planted around the bar, covered by "Bougainvillea glabra" and lit by colored markers.

Entity 5: The Children's play area is a playground dedicated for children from three to 10 years old. It filled with toboggans, swings, and nets for climbing activity. The lining of this space is made of colored clay in semi-circular shapes, in harmony with the general shape of the entity. A border in «Pelargonium peltatum» and colored markers to give more atmosphere marks the route.

Entity 6: the Sports area is he first terrace of the space is flat; it presents the ideal location for the establishment of a practice area of warm-up exercises. Indeed, she is busy with a few activities, made of wood, such as extension arm beams, horizontal floor abs, foot-joint jumps, and nets for climbing activity. The fence protecting the park on 
this side accompanied by an alignment of "Acacia dilbata". The layout of this entity marked by a border of "Rosmarinus officinalis" and recessed floors shaped "Yin Yang" with four "Salix babylonica" creating a "Zen" atmosphere giving a feeling of relaxation and joy. Planting holes of "Salix babylonica", covered with wood, used as benches.

Entity 7: The Reading Space is dedicated to the students of the college of which it is composed of six wooden kiosks, an afforestation of "Pinus Halepensis" and secured by a concealed fence in "Acacia dilbata".

Entity 8: In the BBQ area, two rock corners are proposed and made up of "Agave americana 'Marjinata'", "Crasula tetragona", "Grenovia aurea", "Sansevieria" and "Yucca gloriosa", delimiting the path of passage to the second treasure "Family and history". By lying at the barbecue area, a chessboard in the center attracts attention. It surrounded by a set of wooden balances with, at the corners, planting holes, including a wooden bench and $3 / 4$ for planting four "Elaeagnus angustifolia". The space provided on an altitude of $50 \mathrm{~m}$, which offers a pleasant open view, for this reason it is converted into a barbecue area. On the right side of the chessboard, four tables in natural stones with a parasol in the center of each arranged. On the left side we have the same design but two barbecues «Lantana Camara» surrounds areas (a round table and 6 rectangular barbecues). The tables accompanied by a planter in "Zinnia elegans" and flowerbeds. A Roman-style corner, surrounded above by "Plumpago capensis", below by "Gynerium argentum", is implanted to give a historical aspect to the entity, and presents the historical identity of the city of Ksour Essef through beams from Roman times and three mosaic paintings.

Entity 9: The Panoramic View Area brings us to the third terrace and the third treasure "dream and hope". In this part, the altitude reaches $65 \mathrm{~m}$ offering a panoramic view open on all sides, for this reason, the idea of development was to install three wooden watchtowers occupied telescopes to give users the chance to live the adventure from hunting to great treasure. Thus, soil-fixing works take place in this part of the park, playing the protective role of the soil and a bench for the users.

Entity 10: The Network Distribution Construction Crossroads is centered on an "Elaeagus angustifolia", and surrounded by four planters of "Petunia hybrida" of four colors.

Entity 11: The parking is arranged in $45^{\circ}$ to increase the number of places and for the shade, the "Ficus nitida" be used.

\section{DISCUSSION}

The cities peri-urban green lung parks represent the new tools of spatial planning; they are also green infrastructures that contribute to the organisation of the hinterland of the new urban areas. Here the peri-urban park of ksour essef, shows well following a geographical evaluation of its natural resources, as well as a landscape diagnosis based on spatial, sensitive and social aspects, it was possible to show that despite the constraints and threats that hinder the development of this park on different levels (social, environmental and economic), there is a remarkable natural wealth, a sensitivity of citizens to the importance of this space in improving their living environment, as well as the awareness of local authorities (municipality of Ksour Essef) of the importance of this park in the development of the city and also in the enhancement of the urban environment and in the preservation of nature and its biodiversity. The concept of "treasure hunt" is a guiding idea that respects the environmental conditions, the needs of the population concerned by the park's redevelopment project and the requirements of sustainable development. The objective was to encourage residents of different age groups to discover this natural space in a way that promotes the link between natural and urban.

\section{CONCLUSION}

Combining the management of sensitive areas with landscape analysis is an important discovery, analysis and decision-making process for sustainable landscape management. By protecting and managing natural and public lands in an environementally sensitive manner will help decision makers. The conservation of a peri-urban forest and its environmental managment makes it possible to remedy the negative impacts of anthropogenic events (deforestation, fires, urbanization,). These natural spaces converted into public parks offer services for society and improve the urban environment. However, this ecological development consists of ensuring visitors to the El Hmeda Forest Park the practice of sports activities in the natural environment to maintain good health, escape from a sedentary lifestyle and protect against several diseases threatening people in cites. 


\section{SOURCES OF FUNDING}

This research received no specific grant from any funding agency in the public, commercial, or not-for-profit sectors.

\section{CONFLICT OF INTEREST}

The author have declared that no competing interests exist.

\section{ACKNOWLEDGMENT}

None.

\section{REFERENCES}

[1] Papillon P., 2014, Les forêts périurbaines : des espaces récréatifs à la fonction prophylactique : le cas des aires urbaines d'Alençon, de Blois et du Mans. Géographie. Université du Maine.

[2] Pau F J Eagles. 1981. Environementally Sensitive Area Planning in Ontario, Canada. Journal of the American planning Association. 47: 313-323

[3] Observatory of the Sahara and Sahel (OSS) 2003. Map of sensitivity to desertification in the Mediterranean basin, Proposal for the methodology for the final map, Rome.

[4] Mohamed Cherif, « Dynamique de l'agriculture périurbaine autour des villes moyennes: l'exemple de la ville de Mahdia (Tunisie) », Les Cahiers d'Outre-Mer, 263 |

[5] CRDA, 2014. Regional Report of Mahdia. $70 \mathrm{p}$

[6] God A, Lotfy I, 2008. Use of remote sensing and GIS in mapping the environmental sensitivity areas for desertification of Egyptian territory. Earth Discussion, 3: 41-85

[7] Khebour Allouche Faiza and Gad Abdallah. 2014. A Comparison of Methods for Mapping the Environmental Sensitivity Areas for Desertification of a Mediterranean Landscape Using Remote Sensing and GIS Applications. European Academic Research. Vol II. Issue 8. 